\title{
Review: Can Toxic Substances Initiate Psychotic Behavior? Part I. Antimalarial
} Drugs

\author{
Ilia Brondz \\ Norwegian Drug Control and Drug Discovery Institute (NDCDDI) AS, Ski, Norway \\ Email: ilia.brondz@gmail.com
}

Received 27 May 2014; revised 29 June 2014; accepted 19 July 2014

Copyright (C) 2014 by author and Scientific Research Publishing Inc.

This work is licensed under the Creative Commons Attribution International License (CC BY).

http://creativecommons.org/licenses/by/4.0/

(c) (i) Open Access

\section{Abstract}

During and after every military conflict or war, there appears to be rapports about military crimes which were done by military and civil personal of conflicting sides. The basis of these offences is different; however the common to these is psychological and psychical background. The psychological background is an indoctrination of troopers that all what they are doing is right, well for country, nation or defends religion, or ideology. The life and property of enemy (opponent) are less worth than their oven. But most important in this indoctrination is the direct or indirect insurances about the absence of responsibility and promises about free for punishment for these actions. These aspects are well known and well-studied. The psychical background is less studied and more diverse; however in all cases the components of stress are present. The stress can be physical, psychical or toxic. The physical and psychical stress of engaged in military conflict personal is well studied, its action both during the war and as postwar syndrome have sufficient explanations. The action of intoxication especially by contaminants in medical forms, or toxins to induce the criminal behavior of military personal is nearly unstudied. The exceptions are alcohol, psychogenic substances as narcotics, LSD and special doping agents. This paper presented the evidences of additional toxic stress by contaminates in medical forms and intoxication by toxins of military personal engaged in different conflicts during last decades. The hypothesis about the influences of the additional toxic stress by medication with low quality pharmaceutical forms and some toxins on inducing the crimes generally and war crimes by military personal is launched in the paper. In this part the investigation will be concentrated on antimalarial drugs, especially on contaminated primaquine. Primaquine has a special position in preventing malaria infection in areas of conflict on the territories of endemic malaria. The possibility of induction of psychotic cases which lead to uncontrolled by person its-self actions and which are of criminal nature will be discussed, together with juridical responsibilities for these actions.

\section{Keywords}

Contaminated Medical Forms, Primaquine, Toxic Contaminants, Malaria, 


\section{Introduction}

\subsection{The Specific Type of Crimes Committed by Military Personal}

During every war the engaged sides are committing war crimes. The war crimes of losers are often more exposed to public knowledge. The first international tribunal in Nuremberg exposed to public most notorious military crimes and crimes against humanity committed by Nazis. In the last decades, permanent International tribunal was established in Haag to take care on the military crimes and crimes against humanity. There are many national tribunals taking care on military crimes mostly committed by anime' troops. Some crimes committed by allay and national troops also were exposed to public knowledge. In this paper the interest was to study the cases committed by soldiers against their comrades by shooting them. There are impossibilities to receive the documents about the interrogation of the accused and detailed documentation from military courts. Often the person committing the crime shoots himself or is killed in the action. However, sometime it was known in press, that the accused persons could not give a tangible account or reason for their actions. Often the shootings were initiated by reasons which in normal situation (even a war situation) should not lead to this kind of reactions. It looks like the other reasons than the normally taken in account were present. Because of secrecy it is difficult to give correct picture based on documentation of interrogations and military court judgments or the evidences which were taken in account. However, under no circumstances it was mentioned that toxic medication or contact with toxins could initiate psychotic mood by accused, which could be a reason for tragic results. In this paper this aspect is discussed and the hypothesis about the toxic initiated psychosis as a trigger to tragic results is launched. The possibility of initiate psychotic mood by accused with non-proper quality of medical forms of drugs and or contact with toxins should be studied more carefully, and possibly this aspect must be taken in account by society, military and courts in similar cases in the future and also retrospective.

\subsection{The Geography of Endemic Malaria Coinciding with Military Actions}

In beginning of $20^{\text {th }}$ century endemic malaria was present nearly in all humid tropics in Africa, Southern America and Asia. Distribution of malaria is shown on Figure 1.

Military activities in several of endemic malaria regions as Korea, Vietnam, Iraq and Afghanistan will be discussed. Neither the time for incidents, not precise locations or names of accused or victims will be given, because of privacy security and the author self-restriction to intervene in integrity of military courts decisions. However, most of cases are similar to shootings at Fort Hood, USA happened 03.04.14. In the press was only mentioned that Iraq veteran kills three people at Texas military base Fort Hood, 16 injured as gunman, who was receiving psychiatric help, went on shooting spree before killing himself. The suspect, a soldier who had served in Iraq, he "had behavioral health and mental health" issues. There was no known motive for the shooting, the general Milley said.

The most of these cases are known from American and Grate British troops, however it is no ground to believe that similar incidents were absent among the troops of other nationalities. The most correct explanation to this is that the American and Grate British society is an open to the press, and press in these countries is active and free in more extends than in the others.

\subsection{The Necessity for Military to Protect Troopers and Domestic Civil Population against Malaria Infection}

It is well-known fact that during World War I (1914-1918) Allies imposed the blockade on the import of quinine and bark from Cinchona officinalis L., and C. pubescens Vahl, to Germany and German troops in Africa suffered immense problems with malaria [1]. In all geographic regions with endemic malaria the troopers are exposed to be infected with malaria as it was in Korea war, Vietnam war, in both wars in Iraq and war in Afghanistan. 


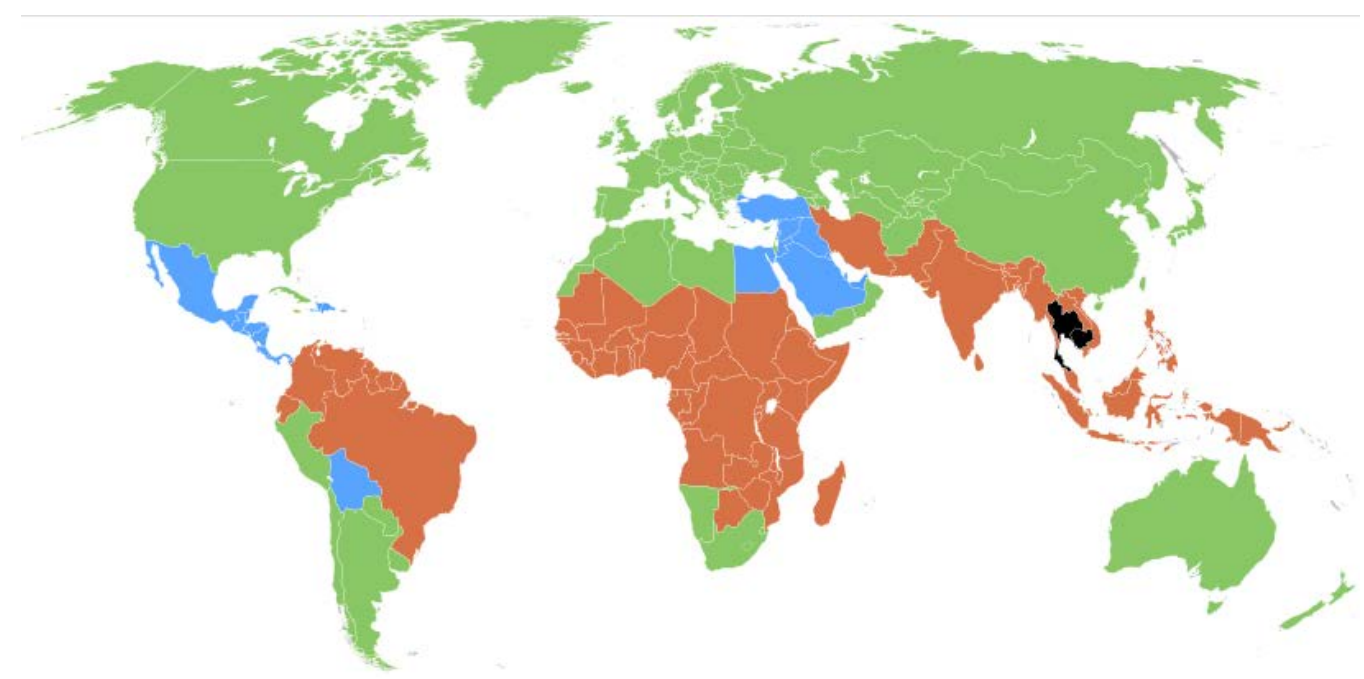

Figure 1. Blue zone is chloroquine sensitive malaria, red zone is chloroquine resistant malaria, and black zone is multi-resistant malaria.

\subsubsection{History of Problem}

Malaria is vector born infection blood diseases. It is strong dependent from the presence of suitable vector and infected host. The detailed geographic distribution of malaria and types of malaria vector (carriers) described in [1]-[3].

Before discovery of synthetic antimalarial drugs quinine was a single remedy against malaria diseases. About 1630, Jesuits, working in South America (Peru) received the knowledge that the bark from cinchona trees was used by the native people as drug against malaria. A variety of alkaloids, including cinchonine, cinchonidine, quinine, quinidine, dihydroquininidine, and dihydroquinine were discovered later in the bark of these trees.

Jesuit Cardinal John de Lugo (1583 - 1660) [1] received the honor for introduction of the bark of cinchona in Europe. The alkaloids present in the bark of cinchona shown in Figure 2.

These alkaloids were a long time an only medication against malaria. As it was presented above malaria strong depends on presence of three factors: malaria parasite, suitable vector and host organism in biosphere. The first factor is a parasite. There are several types of parasites cause malaria in humans: Plasmodium vivax, $P$. ovale, $P$. malariae and $P$. falciparum. There are many subtypes and local variants for every type of this parasite. The second factor is a vector. The main vector for these parasites is Anopheline mosquitoes [1] [3]. When humans were bitten by Anopheline mosquitoes infected with malaria parasite they became ill with malaria, but in the same time they became a part of malarial biosphere as a carrier of a pool of parasites in their blood [1]. The third factor is the presence of humans as natives, tourists, migrant workers or foreign military personal in malaria endemic arias, the humans who are carrier of a pool of parasites in their blood.

Humans infected in one endemic aria by malaria can by traveling to the other aria which was before free from malaria or free from particular type or subtype of parasite introduce or reintroduce in this aria a new type or sub-type of parasite [1] [2] and expose the entire population of this aria for malarial infection. Especially significance of this dangerous situation present when large contingents of troopers return home from infected by malaria endemic aria. The sanitation from malaria of return home contingent of troopers is a priority for health authorities.

Prevention of introduction of malaria parasite strains from Korea was first used on large scale when US troops returned home from Korea war by ships. More than 330,000 men and women each received a single $15 \mathrm{mg}$ daily dose of primaquine during the 14-day Pacific Ocean crossing [4].

\subsubsection{Synthetic Antimalarial Drugs}

As it was mentioned in paragraph 1.3. of this paper the needs for substituents of quinine and bark from cinchona trees was grate and acute in Germany already during the World War I. Robert B. Woodward and William von Doering reported a successful synthesis of quinotoxine and conversion of quinotoxine into quinine in time 
<smiles>C=CC1CN2CCCC1N2C[C@@H](O)c1ccnc2ccc(OC)cc12</smiles>

Quinine<smiles>CCC1CN2CCC1N2C[C@H](O)c1ccnc2ccc(OC)cc12</smiles>

Dihydroquinine<smiles>C=CC1CN2CCC1C[C@@H]2[C@@H](O)c1ccnc2ccc(OC)cc12</smiles>

Quinidine<smiles>CCC1CN2CCC1N2C[C@H](O)c1ccnc2ccc(OC)cc12</smiles>

Dihydroquinidine

Figure 2. The alkaloids present in the bark of cinchona.

of World War II; however, it was a very poorly documented procedure, never successfully realized. A method for preparation of chloroquine an antimalarial drug by the condensation of 4,7-dichloroquinoline with 1-diethylamino-4-aminopentane was patented in Germany, patent 683, 692 in 1939. The structure of chloroquine is depicted in Figure 3.

Chloroquine is quite toxic drug. The need for synthetic substances with antimalarial properties persisted also after discovery of chloroquine. In 1946 Elderfield et al., [5] reported successful synthesis of long list of substances with antimalarial activity; the primaquine was chosen as the more suitable and active substance in this series of aminoquinoline analogs. Elderfield et al., also reported the substance later known in USSR as Quinocide. Quinocide is more toxic than primaquine. Table 1 shows the analogs of aminoquinoline synthesized and tested by Elderfield et al.

Despite of the fact that nearly 70 years got from the first successful use of primaquine this drug do not lost its importance in the struggle against malaria [1]. However, the drug is quite toxic and its therapeutic dose is not fare from toxic and for some of people the therapeutic dose is a toxic dose [1]. Tolerance to primaquine of some people is quite low.

\subsubsection{Tolerance to Primaquine}

Tolerance to primaquine in Caucasians to the usual therapeutic doses of primaquine is quite good. However, the tolerance to primaquine in Negroes is essentially lover [1] [6]. The incidence and degree of anemia and intravascular hemolysis are greater in Negroes at a daily dose level of $20 \mathrm{mg}$ (base) and higher [6]. In some Caucasian ethnic groups, including Sardinians, Sephardic Jews, Greeks and Iranians, in whom the tolerance to primaquine is even, lower than in the Negro so that the hemolytic reaction from a given dose of drug may be more severe [6]. The main disadvantage of primaquine and all 8-aminoquinolines is that the drugs cause methemoglo- 


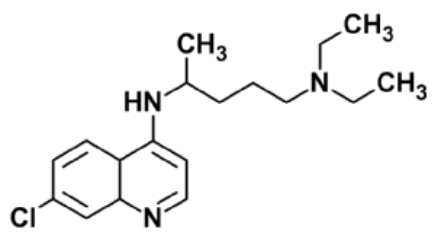

$N^{4}$-(7-chloro-4a,8a-dihydroquinolin-4-yl)- $N^{1}, N^{1}$-diethylpentane-1,4-diamine

Figure 3. The structure of chloroquine.

Table 1. The list of substances with antimalarial activity reported in [5] by Elderfield et al., in 1946.

Numbering of the atoms in rings of aminoquinoline

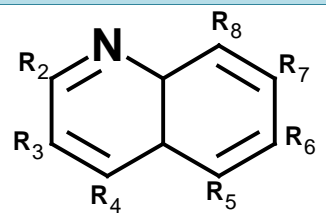

Substance number or name in rapport ofElderfield et. al.

4

5

6

8

9

10

11

12

13

14

15

16

17

18Primaquine

19

20

21

22

23

24
$\mathrm{R}_{8}$ substituents

Other R substituents

\begin{tabular}{|c|c|}
\hline $\mathrm{NH}\left(\mathrm{CH}_{2}\right)_{2} \mathrm{~N}\left(\mathrm{C}_{2} \mathrm{H}_{5}\right)_{2}$ & $\mathrm{R}_{6}=\mathrm{OCH}_{3}$ \\
\hline $\mathrm{NH}\left(\mathrm{CH}_{2}\right)_{3} \mathrm{~N}\left(\mathrm{C}_{2} \mathrm{H}_{5}\right)_{2}$ & $\mathrm{R}_{6}=\mathrm{OCH}_{3}$ \\
\hline $\mathrm{NH}\left(\mathrm{CH}_{2}\right)_{3} \mathrm{NHCH}\left(\mathrm{CH}_{3}\right)_{2}$ & $\mathrm{R}_{6}=\mathrm{OCH}_{3}$ \\
\hline $\mathrm{NHCH}\left(\mathrm{CH}_{3}\right)\left(\mathrm{CH}_{2}\right)_{3} \mathrm{~N}\left(\mathrm{C}_{2} \mathrm{H}_{5}\right)_{2}$ & $\mathrm{R}_{5}=\mathrm{R}_{6}=\mathrm{OCH}_{3}$ \\
\hline $\mathrm{NHCH}\left(\mathrm{CH}_{3}\right)\left(\mathrm{CH}_{2}\right)_{3} \mathrm{NHCH}\left(\mathrm{CH}_{3}\right)_{2}$ & $\mathrm{R}_{5}=\mathrm{R}_{6}=\mathrm{OCH}_{3}$ \\
\hline $\mathrm{NHCH}\left(\mathrm{CH}_{3}\right)\left(\mathrm{CH}_{2}\right)_{3} \mathrm{~N}\left(\mathrm{C}_{2} \mathrm{H}_{5}\right)_{2}$ & $\mathrm{R}_{5}=\mathrm{Cl} ; \mathrm{R}_{6}=\mathrm{OCH}_{3}$ \\
\hline $\mathrm{NH}\left(\mathrm{CH}_{2}\right)_{3} \mathrm{~N}\left(\mathrm{C}_{2} \mathrm{H}_{5}\right)_{2}$ & $\mathrm{R}_{5}=\mathrm{Cl} ; \mathrm{R}_{6}=\mathrm{OCH}_{3}$ \\
\hline $\mathrm{NH}\left(\mathrm{CH}_{2}\right)_{3} \mathrm{~N}\left(\mathrm{C}_{2} \mathrm{H}_{5}\right)_{2}$ & $\mathrm{R}_{5}=\mathrm{R}_{6}=\mathrm{OCH}_{3}$ \\
\hline $\mathrm{NH}\left(\mathrm{CH}_{2}\right)_{3} \mathrm{~N}\left(\mathrm{C}_{2} \mathrm{H}_{5}\right)_{2}$ & $\mathrm{R}_{2}=\mathrm{C}_{6} \mathrm{H}_{5}$ \\
\hline $\mathrm{NH}\left(\mathrm{CH}_{2}\right)_{3} \mathrm{~N}\left(\mathrm{C}_{2} \mathrm{H}_{5}\right)_{2}$ & $\mathrm{R}_{2}=\mathrm{C}_{6} \mathrm{H}_{5} ; \mathrm{R}_{6}=\mathrm{OCH}_{3}$ \\
\hline $\mathrm{NH}\left(\mathrm{CH}_{2}\right)_{2} \mathrm{NHC}_{2} \mathrm{H}_{5}$ & $\mathrm{R}_{6}=\mathrm{OCH}_{3}$ \\
\hline $\mathrm{NH}\left(\mathrm{CH}_{2}\right)_{5} \mathrm{~N}\left(\mathrm{C}_{2} \mathrm{H}_{5}\right)_{2}$ & $\mathrm{R}_{6}=\mathrm{OCH}_{3}$ \\
\hline $\mathrm{NH}\left(\mathrm{CH}_{2}\right)_{3} \mathrm{O}\left(\mathrm{CH}_{2}\right)_{3} \mathrm{~N}\left(\mathrm{C}_{2} \mathrm{H}_{5}\right)_{2}$ & $\mathrm{R}_{6}=\mathrm{OCH}_{3}$ \\
\hline $\mathrm{NH}\left(\mathrm{CH}_{2}\right)_{3} \mathrm{~N}\left(\mathrm{C}_{2} \mathrm{H}_{5}\right)_{2}$ & $\mathrm{R}_{6}=\mathrm{OH}$ \\
\hline $\mathrm{NH}\left(\mathrm{CH}_{2}\right)_{3} \mathrm{~N}\left(\mathrm{C}_{2} \mathrm{H}_{5}\right)_{2}$ & $\mathrm{R}_{5}=\mathrm{OC}_{6} \mathrm{H}_{5} ; \mathrm{R}_{6}$ \\
\hline $\mathrm{NH}\left(\mathrm{CH}_{2}\right)_{6} \mathrm{NHCH}\left(\mathrm{CH}_{3}\right)_{2}$ & $\mathrm{R}_{6}=\mathrm{OCH}_{3}$ \\
\hline $\mathrm{NH}\left(\mathrm{CH}_{2}\right)_{6} \mathrm{NHCH}_{2} \mathrm{CH}_{2} \mathrm{CH}_{3}$ & $\mathrm{R}_{6}=\mathrm{OCH}_{3}$ \\
\hline $\mathrm{NHCH}\left(\mathrm{CH}_{3}\right)\left(\mathrm{CH}_{2}\right)_{3} \mathrm{NH}_{2}$ & $\mathrm{R}_{6}=\mathrm{OCH}_{3}$ \\
\hline $\mathrm{NHCH}\left(\mathrm{CH}_{3}\right)\left(\mathrm{CH}_{2}\right)_{3} \mathrm{NHC}_{2} \mathrm{H}_{5}$ & $\mathrm{R}_{6}=\mathrm{OCH}_{3}$ \\
\hline $\mathrm{NHCH}\left(\mathrm{CH}_{3}\right)\left(\mathrm{CH}_{2}\right)_{3} \mathrm{NHCH}\left(\mathrm{CH}_{3}\right)_{2}$ & $\mathrm{R}_{6}=\mathrm{OCH}_{3}$ \\
\hline $\mathrm{NH}\left(\mathrm{CH}_{2}\right)_{6} \mathrm{NHCH}_{3}$ & $\mathrm{R}_{6}=\mathrm{OCH}_{3}$ \\
\hline $\mathrm{NH}\left(\mathrm{CH}_{2}\right)_{3} \mathrm{CH}\left(\mathrm{C}_{2} \mathrm{H}_{5}\right) \mathrm{NHC}_{2} \mathrm{H}_{5}$ & $\mathrm{R}_{6}=\mathrm{OCH}_{3}$ \\
\hline $\mathrm{NHCH}\left(\mathrm{CH}_{3}\right)\left(\mathrm{CH}_{2}\right)_{2} \mathrm{CH}\left(\mathrm{CH}_{3}\right) \mathrm{N}\left(\mathrm{C}_{2} \mathrm{H}_{5}\right)_{2}$ & $\mathrm{R}_{6}=\mathrm{OCH}_{3}$ \\
\hline $\mathrm{NH}\left(\mathrm{CH}_{2}\right)_{3} \mathrm{CH}\left(\mathrm{NH}_{2}\right)\left(n-\mathrm{C}_{4} \mathrm{H}_{9}\right)$ & $\mathrm{R}_{6}=\mathrm{OCH}_{3}$ \\
\hline
\end{tabular}




\begin{tabular}{|c|c|c|}
\hline \multicolumn{3}{|c|}{ Continued } \\
\hline 25 & $\mathrm{NH}\left(\mathrm{CH}_{2}\right)_{3} \mathrm{~N}\left(\mathrm{C}_{2} \mathrm{H}_{5}\right)_{2}$ & $\mathrm{R}_{5}=p-\mathrm{OCH}_{3} \mathrm{C}_{6} \mathrm{H}_{4} ; \mathrm{R}_{6}=\mathrm{OCH}_{3}$ \\
\hline 26 & $\mathrm{NHCH}\left(\mathrm{CH}_{3}\right)\left(\mathrm{CH}_{2}\right)_{3} \mathrm{NHCH}_{2} \mathrm{CH}_{2} \mathrm{CH}_{3}$ & $\mathrm{R}_{6}=\mathrm{OCH}_{3}$ \\
\hline 27 & $\mathrm{NH}\left(\mathrm{CH}_{2}\right)_{7} \mathrm{~N}\left(\mathrm{C}_{2} \mathrm{H}_{5}\right)_{2}$ & $\mathrm{R}_{6}=\mathrm{OCH}_{3}$ \\
\hline 28 & $\mathrm{NH}\left(\mathrm{CH}_{2}\right)_{2} \mathrm{~N}\left(\mathrm{C}_{2} \mathrm{H}_{5}\right)_{2}$ & $\mathrm{R}_{2}=\mathrm{CH}_{3}$ \\
\hline 29 & $\mathrm{NH}\left(\mathrm{CH}_{2}\right)_{6} \mathrm{~N}\left(\mathrm{C}_{2} \mathrm{H}_{5}\right)_{2}$ & $\mathrm{R}_{2}=\mathrm{CH}_{3}$ \\
\hline 30 & $\mathrm{NH}\left(\mathrm{CH}_{2}\right)_{2} \mathrm{~N}\left(\mathrm{C}_{2} \mathrm{H}_{5}\right)_{2}$ & $\mathrm{R}_{4}=\mathrm{CH}_{3}$ \\
\hline 31 & $\mathrm{NH}\left(\mathrm{CH}_{2}\right)_{6} \mathrm{~N}\left(\mathrm{C}_{2} \mathrm{H}_{5}\right)_{2}$ & $\mathrm{R}_{4}=\mathrm{CH}_{3}$ \\
\hline 32 & $\mathrm{NH}\left(\mathrm{CH}_{2}\right)_{6} \mathrm{~N}\left(\mathrm{C}_{2} \mathrm{H}_{5}\right)_{2}$ & $\mathrm{R}_{5}=\mathrm{CH}_{3} ; \mathrm{R}_{6}=\mathrm{OCH}_{3}$ \\
\hline 33 & $\mathrm{NH}\left(\mathrm{CH}_{2}\right)_{2} \mathrm{~N}\left(\mathrm{C}_{2} \mathrm{H}_{5}\right)_{2}$ & $\mathrm{R}_{6}=\mathrm{Cl}$ \\
\hline 34 & $\mathrm{NH}\left(\mathrm{CH}_{2}\right)_{6} \mathrm{~N}\left(\mathrm{C}_{2} \mathrm{H}_{5}\right)_{2}$ & $\mathrm{R}_{6}=\mathrm{Cl}$ \\
\hline 35 & $\mathrm{NH}\left(\mathrm{CH}_{2}\right)_{6} \mathrm{NHCH}\left(\mathrm{CH}_{3}\right)_{2}$ & $\mathrm{R}_{5}=\mathrm{R}_{6}=\mathrm{OCH}_{3}$ \\
\hline 36 & $\mathrm{NH}\left(\mathrm{CH}_{2}\right)_{6} \mathrm{~N}\left(\mathrm{C}_{2} \mathrm{H}_{5}\right)_{2}$ & $\mathrm{R}_{6}=\mathrm{CH}_{3}$ \\
\hline 37 & $\mathrm{NH}\left(\mathrm{CH}_{2}\right)_{2} \mathrm{~N}\left(\mathrm{C}_{2} \mathrm{H}_{5}\right)_{2}$ & $\mathrm{R}_{6}=\mathrm{CH}_{3}$ \\
\hline 38 & $\mathrm{NHCH}\left(\mathrm{CH}_{3}\right)\left(\mathrm{CH}_{2}\right)_{3} \mathrm{NHCH}_{2} \mathrm{CH}\left(\mathrm{CH}_{3}\right)_{2}$ & $\mathrm{R}_{6}=\mathrm{OCH}_{3}$ \\
\hline 39 & $\mathrm{NHCH}\left(\mathrm{CH}_{3}\right)\left(\mathrm{CH}_{2}\right)_{3} \mathrm{NHC}\left(\mathrm{CH}_{3}\right)_{3}$ & $\mathrm{R}_{6}=\mathrm{OCH}_{3}$ \\
\hline 40 & $\mathrm{NH}\left(\mathrm{CH}_{2}\right)_{2} \mathrm{~N}\left(\mathrm{C}_{2} \mathrm{H}_{5}\right)_{2}$ & $\mathrm{R}_{2}=\mathrm{R}_{6}=\mathrm{CH}_{3}$ \\
\hline 41 & $\mathrm{NH}\left(\mathrm{CH}_{2}\right)_{2} \mathrm{~N}\left(\mathrm{C}_{2} \mathrm{H}_{5}\right)_{2}$ & $\mathrm{R}_{7}=\mathrm{CH}_{3}$ \\
\hline 42 & $\mathrm{NH}\left(\mathrm{CH}_{2}\right)_{2} \mathrm{~N}\left(\mathrm{C}_{2} \mathrm{H}_{5}\right)_{2}$ & $\mathrm{R}_{7}=\mathrm{CH}_{3}$ \\
\hline 43 & $\mathrm{NH}\left(\mathrm{CH}_{2}\right)_{2} \mathrm{~N}\left(\mathrm{C}_{2} \mathrm{H}_{5}\right)_{2}$ & $\mathrm{R}_{5}=\mathrm{OCH}_{3}$ \\
\hline 44 & $\mathrm{NH}\left(\mathrm{CH}_{2}\right)_{6} \mathrm{~N}\left(\mathrm{C}_{2} \mathrm{H}_{5}\right)_{2}$ & $\mathrm{R}_{2}=\mathrm{R}_{4}=\mathrm{CH}_{3}$ \\
\hline 45 & $\mathrm{NH}\left(\mathrm{CH}_{2}\right)_{6} \mathrm{~N}\left(\mathrm{C}_{2} \mathrm{H}_{5}\right)_{2}$ & $\mathrm{R}_{5}=\mathrm{CH}_{3}$ \\
\hline 46 & $\mathrm{NH}\left(\mathrm{CH}_{2}\right)_{6} \mathrm{~N}\left(\mathrm{C}_{2} \mathrm{H}_{5}\right)_{2}$ & $\mathrm{R}_{5}=\mathrm{OCH}_{3}$ \\
\hline 47 & $\mathrm{NH}\left(\mathrm{CH}_{2}\right)_{6} \mathrm{~N}\left(\mathrm{C}_{2} \mathrm{H}_{5}\right)_{2}$ & $\mathrm{R}_{2}=\mathrm{R}_{6}=\mathrm{CH}_{3}$ \\
\hline 48 & $\mathrm{NHCH} 2 \mathrm{CHOH}\left(\mathrm{CH}_{2}\right)_{2} \mathrm{NHC}_{2} \mathrm{H}_{5}$ & $\mathrm{R}_{6}=\mathrm{OCH}_{3}$ \\
\hline 49 & $\mathrm{NH}\left(\mathrm{CH}_{2}\right)_{6} \mathrm{~N}\left(\mathrm{C}_{2} \mathrm{H}_{5}\right)_{2}$ & $\mathrm{R}_{4}=\mathrm{Cl}$ \\
\hline
\end{tabular}

binemia, however the other toxic effects of primaquine and 8-aminoquinolines should not been overseen [1]. It should be mentioned that pure primaquine as pro analyses grade never was biologically tested out, the substance always was contaminated with quinocide [1] [7]-[22].

\subsubsection{Toxicity and Neurotoxicity of Primaquine and 8-aminoquinolines}

Primaquine and all 8-aminoquinolines strong differ from natural antimalarial present in bark of cinchona trees. Quinine has a number of abilities; it kills mono- and multi-cellular organisms like bacteria, fungi, protozoa, insects, parasites, germs, reduces fever, reduces spasms, calms nerves, relieves pain, stimulates digestion and regulates the heartbeat [1]. Quinine is moderate toxic for humans'. The structure of primaquine is shown on Figure 4.

Some of batches of primaquine are heavily contaminated with quinocide [1], [7]-[22]. Quinocide is more toxic than primaquine [1] the structure of quinocide is shown on Figure 5.

Contamination of primaquine with $6 \%$ of quinocide elevates the toxicity of this mixture twice in comparison to primaquine with $0.5 \%$ quinocide [7]-[8].Primaquine is inducing methemoglobinemia [23]-[26], effects on the red blood cell membrane [27]. Some of polyamines are involved in the development of hepatic encephalopathy 


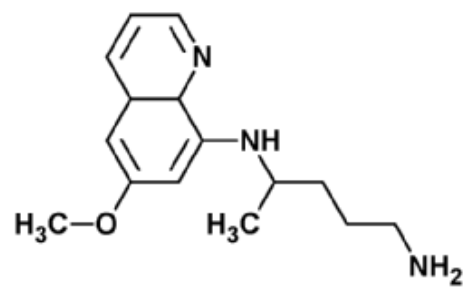

$N^{4}$-(6-methoxy-4a,8a-dihydroquinolin-8-yl)pentane-1,4-diamine

Primaquine

Figure 4. Structure of primaquine.<smiles>COC1=CC2C=CC=NC2C(NCCCC(C)N)=C1</smiles>

$N^{1}$-(6-methoxy-4a,8a-dihydroquinolin-8-yl)pentane-1,4-diamine

Quinocide

\section{Figure 5. Structure of quinocide.}

and cerebral edema [28]. The neurotoxicity of the 8-aminoquinolines [29] [30] is characteristic for these substances. In most of described neuropsychiatric disturbances after malaria prophylaxis were notified with use of mefloquine, plasmocid, clioquinol, plasmochine and rhodoquine [31]-[58]. However, already in 1951 appears that primaquine can exhibit the similar effects in animal models [53]. Later in 1981 Lee et. al., in the Bulletin of World Health Organization [59] supported the observations: "In the present study, the subacute toxicity of primaquine was studied in beagle dogs, rhesus monkeys, and albino rats. ... Certain derivatives of the 8-aminoquinolines have been shown to affect some blood constituents and haemopoiesis, to induce functional changes in the central nervous system, and to cause other organ lesions", and "gliosis of the cerebral cortex in some monkeys".

Despite very broad use of primaquine in curative medicine, more than several hundred million cases per year, the description of neurotoxicity of this drug is very poor presented in literature. The description of neurotoxicity of quinocide is not presented at all; however it is known that combination of different 8-aminoquinolines potentiate toxic effects. In experiments described in [7] and [8] were clear shown that elevation of contamination of primaquine from $0.5 \%$ to $6.0 \%$ doubles the toxicity. In this model the disruption of electron transport chain was studied. Peripheral and central nerve systems are very sensitive to the biochemistry of the disruption of electron transport chain.

\subsubsection{The Situation to Date}

It is unbelievable that the drug used in about of seventy year was presented on the market to these extends contaminated [1] [7] [8] Figure 6.

In Figure 7 shown the document published in [60] which give evidence that batches of primaquine contaminated with more than $8 \%$ were used in productions of medical forms.

The samples even more contaminated were often found. In these circumstances the intoxication could happen.

\subsubsection{The Hypothesis and Consequences}

It is obvious that all 8-aminoquinolines have numerous toxic effects and one of these is neurotoxicity, the mix- 


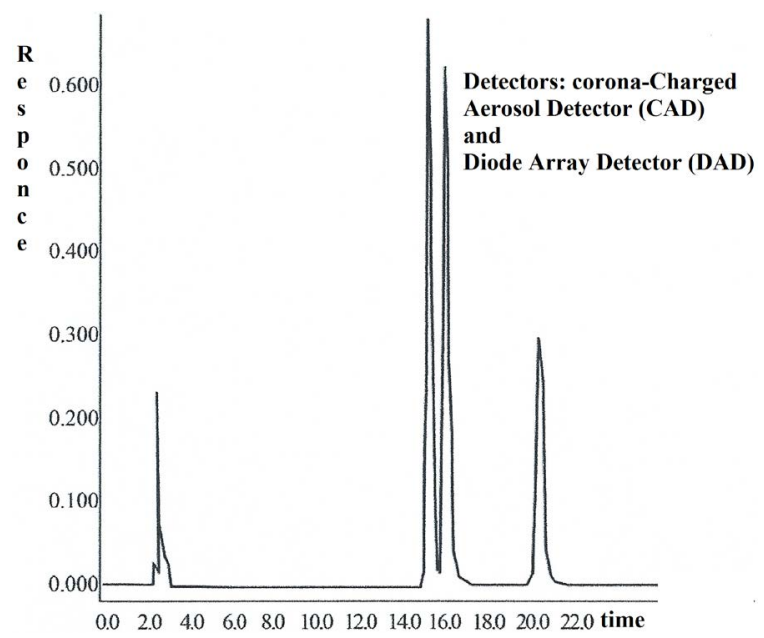

Figure 6. The analytical separation of individual substances in industrial sample of primaquine: peaks between the 14.0 and $18.0 \mathrm{~min}$ are the enantiomers of primaquine, the peak between 19.0 and $22.0 \mathrm{~min}$ is quinocide.

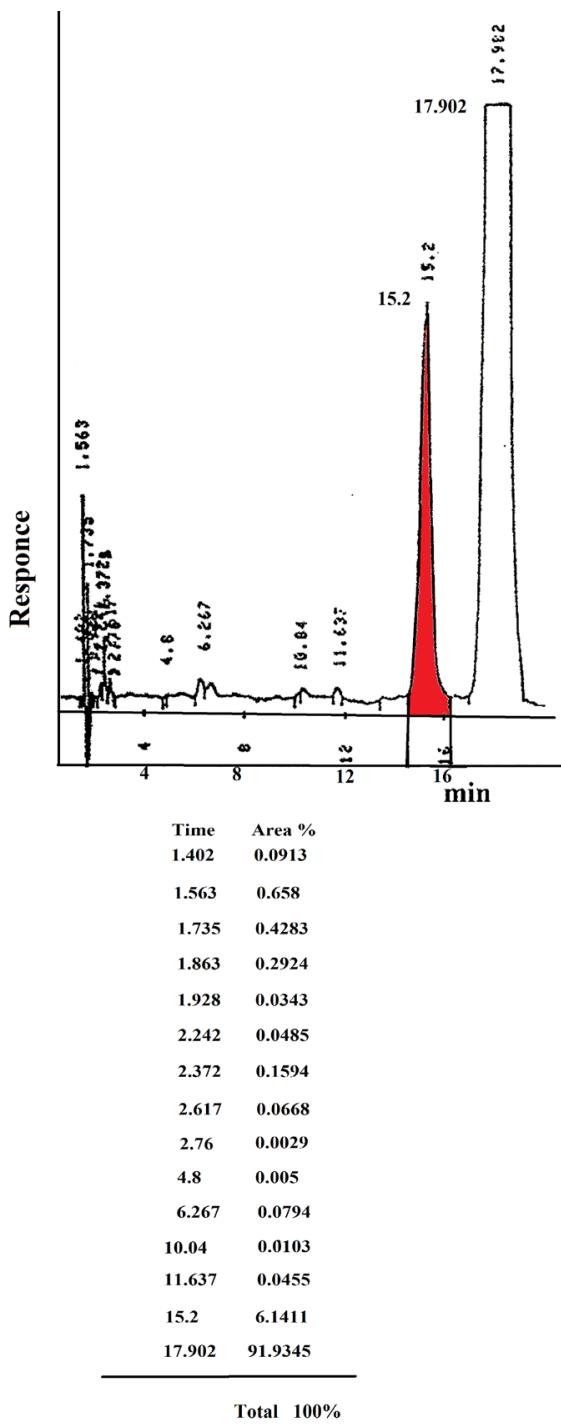

Figure 7. The peak at $15.2 \mathrm{~min}$ is $6.1411 \%$ quinocide in the industrial sample of primaquine. 
ture of several 8-aminoquinolines is more toxic than pure substance. The neuropsychiatric adverse effects of mefloquine is best studied among the 8-aminoquinolines, however the absence of data do not suggests that primaquine or mixture of primaquine with quinocide are harmless. All evidences gathered up to date are suggest that primaquine contaminated with quinocide is a potential neurotoxic drug and can lead to psychotic conditions. The art of these is difficult to predict and the physical and psychical stress can aggravate the situation.

\subsection{Conclusion}

The primaquine is frequently used drug with significant and multiple toxic side effects. Study of its neurotoxic side effect is urgently needed as well as production of non-contaminated by quinocide material. In malarial endemic zones, the use of the pure primaquine as described in [22] by military can be preferable as well as use of the pure primaquine as described in [22] for the population in these zones general. Toxic substances as antimalarial drugs primaquine and others can initiate psychotic behavior in humans.

The military personnel should receive more attention in short and long time terms especially than they were exposed to potent toxic substances with neurotoxic effects.

\section{References}

[1] Brondz, I. (2011) Historical Overview of Chromatography and Related Techniques in Analysis of Antimalarial Drug Primaquine. Nova Science Publishers, Inc., New York.

[2] Stürchler, D. (2001) Global Epidemiology of Malaria. In: Schlagenhauf-Lawlor, P., Ed., Travelers’ Malaria, BC Decker Inc., Hamilton, London, 14-55.

[3] Russell, P.F. and Rozeboom, LE. (1943) Keys to the Anopheline Mosquitoes of the World. The American Entomological Society, The Academy of Natural Sciences, Philadelphia.

[4] Coatney, G.R. and Getz, M.E. (1962) Primaquine and Quinocide as Curative Agents against Sporozoite-Induced Chesson Strain Vivax Malaria. Bulletin of the World Health Organization, 27, 290-293.

[5] Elderfield, R.C., Gensler, W.J., Head, J.D., Hageman, H.A., Kremer, C.B., Wright, J.B., Holley, A.D., Williamson, B., Galbreath, J., Wielderhold, III, L., Flohardt, R., Kupchan, S.M., Williamson, T.A. and Birstein, O. (1946) Alkylaminoalkyl Derivatives of 8-Aminoquinoline. Journal of the American Chemical Society, 38, 1524-1528. http://dx.doi.org/10.1021/ja01212a040

[6] Goodman, L.S. and Gilman, A. (1970) The Pharmacological Basis of Therapeutics. In: Goodman, L.S. and Gilman, A., Eds., A Textbook of Pharmacology, Toxicology, and Therapeutics for Physicians and Medical Students, 4th Edition, Coller-Macmillan Limited, London, Collier-Macmillan Canada Limited, Toronto, 1112-1115.

[7] Brondz, I., Mantzeilas, D., Klein, U., Lebedeva, M.N., Mikhailitsyn, F.S. Souleimanov, G.D. andEkeberg, D. (2003) A 100 Years of Chromatography. 3rd International Symposium on Separation in BioSciences SBS 2003, Moscow, 13-18 May 2003, 165.

[8] Brondz, I., Mantzilas, D., Klein, U., Ekeberg, D., Hvattum, E., Lebedeva, M.N., Mikhailitsyn, F.S., Souleimanov, G.D. and Røe, J. (2004) Nature of the Main Contaminant in the Anti-Malaria Drug Primaquine Di-Phosphate: A Qualitative Isomer Analysis. Chromatography B: Biomedical Sciences and Applications, 800, 211-223.

[9] Brondz, I., Klein, U., Ekeberg, D., Mantzilas, D., Hvattum, E., Schultz, H. and Mikhailitsyn, F.S. (2004) Nature of the Main Contaminant in the Antimalaria Drug Primaquine Diphosphate: GC-MS Analysis. International Symposium Analytical Forum 2004, Warsaw, 4-8 July 2004, 119.

[10] Brondz, I., Klein, U., Ekeberg, D., Mantzilas, D., Hvattum, E., Schultz, H. and Mikhailitsyn, F.S. (2005) Nature of the Main Contaminant in the Anti-Malaria Drug Primaquine Di-Phosphate: GC-MS Analysis. Asian Journal of Chemistry, 17, 1678-1688.

[11] Brondz, I. and Klein, U. (2005) Separation of the Positional Isomer Quinocide from the Anti-Malarial Drug Primaquine Using a Discovery ${ }^{\circledR}$ HS F5 HPLC Column. The Reporter, 23, 1.

[12] Brondz, I., Ekeberg, D., Karaliova, L., Jennings, I., Hustad, J.A. and Svendsen, R. (2005) Separation of the Positional Isomer Quinocide from the Anti-Malaria Drug Primaquine Using a Discovery ${ }^{\circledR}$ HS-F5 HPLC Column. Trends in Chromatography, 1, 78-81.

[13] Brondz, I. and Klein, U. (2006) Separation of the Positional Isomer Quinocide from the Anti-Malarial Drug Primaquine Using a Discovery ${ }^{\circledR}$ HS F5 HPLC Column. The Reporter, 19, 3.

[14] Brondz, I., Ekeberg, D., Bell, D.S., Hustad, J.A., Svendsen, R., Vlachos, V., Oakley, P.G., Langley, J., Mohini, T., Amaury, C.-G. and Mikhalitsyn, F. (2007) Nature of the Main Contaminant in the Drug Primaquine Diphosphate: SFC 
and SFC-MS Methods of Analysis. Journal of Pharmaceutical and Biomedical Analysis, 43, 937-944. http://dx.doi.org/10.1016/j.jpba.2006.09.017

[15] Brondz, I., Ekeberg, D., Annino, A.R. and Palcic, T. (2007) SFC-MS Analyses of Anti-Malaria Drug Primaquine Diphosphate. Comparison of Techniques and Instrumentation. 12 Norwegian MS-Winter Meeting, Hafjell, 21-24 January 2007, 42.

[16] Brondz, I., Fialkov, A.B. and Amirav, A. (2009) Analysis of Quinocide in Unprocessed Primaquine Diphosphate and Primaquine Diphosphate Tablets Using Gas Chromatography-Mass Spectrometry with Supersonic Molecular Beams. Journal of Chromatography A, 1216, 824-829. http://dx.doi.org/10.1016/j.chroma.2008.11.043

[17] Brondz, I. (2009) Chapter 5, SFC-MS Analysis of Contaminants in Primaquine Diphosphate Tablets and Spectral UV and NMR Characterizing of Primaquine and Quinocide, In: Csizmadia, E. and Kalnoky, I., Eds., Antimalarial Drugs: Costs, Safety and Efficacy, Nova Science Publishers, Inc., New York, 105-124.

[18] Brondz, I. (2009) Improved Separation of Quinocide in Primaquine Analysis by Supercritical Fluid ChromatographyMass Spectrometry. 5th Conference Nordic Separation Science Society, Tallinn, 26-29 August 2009, abstr. PP06.

[19] Brondz, I. (2009) SFC-MS Analysis of Contaminants in Primaquine Diphosphate Tablets and Spectral UV and NMR Characterizing of Primaquine and Quinocide. 5th Conference Nordic Separation Science Society, Tallinn, 26-29 August 2009, abstr. PP07.

[20] Brondz, I. (2010) Chapter 6, Historical Overview of Chromatography and Related Techniques in Analysis of Antimalarial Drug Primaquine. In: Quintin, T.J., Ed., Chromatography: Types, Techniques and Methods, Nova Science Publishers, Inc., New York, 281-322.

[21] Brondz, I. (2011) In Vitro Techniques in Analysis of Antimalarial Drug Primaquine (Historical Overview of Chromatography and Related Techniques in Analysis of Antimalarial Drug Primaquine. 7th Annual BioMalPar Conference on the Biology and Pathology of the Malaria Parasite, Heidelberg, 16-18 May 2011, abstr. 54, p. 80.

[22] Brondz, I. and Brondz, A. (2012) The Technology for Preparation of Generic (Monoenantiomeric) Antimalarial Drug Primaquine by Using Supercritical Fluid Chromatography. Separation of Primaquine from Quinocide: Simultaneous Resolution of the Enantiomers of Primaquine and Their Separation from Quinocide in One Run. American Journal of Analytical Chemistry, 3, 884-890. http://dx.doi.org/10.4236/ajac.2012.312A117

[23] Sin, D.D. and Shafran, S.D. (1996) Dapsone- and Primaquine-Induced Methemoglobinemia in HIV-Infected Individuals. Journal of Acquired Immune Deficiency Syndromes \& Human Retrovirology, 12, 477-481. http://dx.doi.org/10.1097/00042560-199608150-00006

[24] Coleman, M.D. and Coleman, N.A. (1996) Drug-Induced Methaemoglobinaemia. Treatment Issues. Drug Safety, 14, 394-405. http://dx.doi.org/10.2165/00002018-199614060-00005

[25] Marrs, T.C., Bright, J.E. and Morris, B.C. (1987) Methemoglobinogenic Potential of Primaquine and Its Mutagenicity in the Ames Test. Toxicology Letters, 36, 281-287. http://dx.doi.org/10.1016/0378-4274(87)90197-4

[26] Gareth, S. and Kantor, M.B. (1992) Primaquine-Induced Methemoglobinemia during Treatment of Pneumocystis carinii Pneumonia. The New England Journal of Medicine, 327, 1461. http://dx.doi.org/10.1056/NEJM199211123272016

[27] Weed, R. (1961) Effects of Primaquine on the Red Blood Cell Membrane. II. K ${ }^{+}$Permeability in Glucose-6-Phosphate Dehydrogenase Deficient Erythrocytes. Journal of Clinical Investigation, 40, 140-143.

http://dx.doi.org/10.1172/JCI104227

[28] Bullimore, D. (1993) The Role of Polyamines in Hepatic Encephalopathy and Cerebral Oedema. European Journal of Gastroenterology \& Hepatology, 5, 63-67. http://dx.doi.org/10.1097/00042737-199302000-00001

[29] Schmidt, I.G. and Schmidt, L.H. (1948) Neurotoxicity of the 8-Aminoquinolines. I. Lesions in the Central Nervous System of the Rhesus Monkey Induced by Administration of Plasmocid. Journal of Neuropathology \& Experimental Neurology, 7, 368-398. http://dx.doi.org/10.1097/00005072-194810000-00002

[30] Schmidt, I.G. and Schmidt, L.H. (1949) Neurotoxicity of the 8-Aminoquinolines. II. Reactions of Various Experimental Animals to Plasmocid. Journal of Comparative Neurology, 91, 337-367. http://dx.doi.org/10.1002/cne.900910303

[31] Aarnoudse, A.L.H.J., van Schaik, R.H.N., Dieleman, J., Molokhia, M., van Riemsdijk, M.M., Ligthelm, R.J., Overbosch, D., van der Heiden, I.P. and Stricker, B.H.C. (2006) MDR1 Gene Polymorphisms Are Associated with Neuropsychiatric Adverse Effects of Mefloquine. Clinical Pharmacology \& Therapeutics, 80, 367-374. http://dx.doi.org/10.1016/j.clpt.2006.07.003

[32] Arasaki, K. and Nakanishi, T. (1989) Selective Neurotoxicity of Clioquinol on the Function of the Posterior Column Nuclei. Neuroscience Letters, 107, 85-88. http://dx.doi.org/10.1016/0304-3940(89)90795-7

[33] Benazet, F. (1963) Pharmacology of 8-Aminoquinolines and Combinations of Various Synthetic Antimalarials. Médecine Tropicale: Revue du Corps de santé colonial, 23, 760-768.

[34] Bernard, J., Le Camus, J., Sarrouy, J., Renaudineau, J., Calami, G., Trifot, M. and Martin, D. (1989) Toxic Encephalo- 
pathy Induced by Mefloquine: 3 Case Reports. Médecine et armées, 17, 209-211.

[35] Björkman, A. (1989) Acute Psychosis Following Mefloquine Prophylaxis. The Lancet, 334, 865. http://dx.doi.org/10.1016/S0140-6736(89)93029-8

[36] Caillon, E., Schmitt, L. and Moron, P. (1992) Acute Depressive Symptoms after Mefloquine Treatment. American Journal of Psychiatry, 149, 712.

[37] Decourt, P. (1936) Studies of the Toxicity of Plasmochine and Rhodoquine. Bulletin de la Société de Pathologie Exotique, 29, 328-336.

[38] Dow, G.S., Hudson, T.H., Vahey, M. and Koenig, M.L. (2003) The Acute Neurotoxicity of Mefloquine May Be Mediated through a Disruption of Calcium Homeostasis and ER Function in Vitro. Malaria Journal, 2, 14. http://dx.doi.org/10.1186/1475-2875-2-14

[39] Dow, G., Bauman, R., Caridha, D., Cabezas, M., Du, F., Gomez-Lobo, R., Park, M., Smith, K. and Cannard, K. (2006) Mefloquine Induces Dose-Related Neurological Effects in a Rat Model. Antimicrobial Agents and Chemotherapy, 50, 1045-1053. http://dx.doi.org/10.1128/AAC.50.3.1045-1053.2006

[40] Ferrier, T.M. and Eadie, M.J. (1973) Clioquinol Encephalopathy. Medical Journal of Australia, 2, 1008-1009.

[41] Grupp, D., Rauber, A. and Fröscher, W. (1994) Neuropsychiatric Disturbances after Malaria Prophylaxis with Mefloquine. Aktuelle Neurologie, 21, 134-136. http://dx.doi.org/10.1055/s-2007-1017970

[42] Hardgrove, M. and Applebaum, I.L. (1946) Plasmochin Toxicity: Analysis of 258 Cases. Annals of Internal Medicine, 25, 103-112. http://dx.doi.org/10.7326/0003-4819-25-1-103

[43] Kaeser, H.E. (1984) Transient Global Amnesia Due to Clioquinol. Acta Neurologica Scandinavica, 100, 175-183.

[44] Lapras, J., Vighetto, M., Trillet, A. and Garin, J.P. (1989) Transient Disorders of Memory after a Malaria Attack. Caused by Mefloquine? Presse Médicale, 18, 776.

[45] Loken, A.C. and Haymaker, W. (1949) Pamaquine Poisoning in Man, with a Clinicopathologic Study of One Case. American Journal of Tropical Medicine and Hygiene, 29, 341-352.

[46] Mawson, A. (2013) Mefloquine Use, Psychosis, and Violence: A Retinoid Toxicity Hypothesis. Medical Science Monitor, 19, 579-583. http://dx.doi.org/10.12659/MSM.889033

[47] Lee, H.S. and Go, M.L. (1996) Effects of Mefloquine on $\mathrm{Ca}^{2+}$ Uptake and Release by Dog Brain Microsomes. Archives internationales de pharmacodynamie et de thérapie, 331, 221-231.

[48] Patchen, L.C., Campbell, C.C. and Williams, S.B. (1989) Neurologic Reactions after a Therapeutic Dose of Mefloquine. The New England Journal of Medicine, 321, 1415-1416. http://dx.doi.org/10.1056/NEJM198911163212017

[49] Schlagenhauf, P. and Steffen, R. (2000) Neuropsychiatric Events and Travel: Do Antimalarials Play a Role? Journal of Travel Medicine, 7, 225-226. http://dx.doi.org/10.2310/7060.2000.00069

[50] Schmidt, I.G. (1947) Effects of Pamaquine on the Central Nervous System. Anatomical Record, $97,367$.

[51] Schmidt, I.G. and Schmidt, L.H. (1947) Studies on the 8-Aminoquinolines; the Effects of Plasmocid on the Central Nervous System. Federation Proceedings, 6, 368.

[52] Schmidt, I.G. and Schmidt, L.H. (1948) Neurotoxicity of the 8-Aminoquinolines. I. Lesions in the Central Nervous System of the Rhesus Monkey Induced by Administration of Plasmocid. Journal of Neuropathology \& Experimental Neurology, 7, 368-398. http://dx.doi.org/10.1097/00005072-194810000-00002

[53] Schmidt, I.G. and Schmidt, L.H. (1951) Neurotoxicity of the 8-Aminoquinolines. III. The Effects of Pentaquine, Isopentaquine, Primaquine, and Pamaquine on the Central Nervous System of the Rhesus Monkey. Journal of Neuropathology \& Experimental Neurology, 10, 231-256. http://dx.doi.org/10.1097/00005072-195107000-00001

[54] Schmidt, L.H. and Smith, C.C. (1947) Studies on the 8-Aminoquinolines; the Toxicities of Pamaquine and Plasmocid in Different Animal Species. Federation Proceedings, 6, 369.

[55] Sipe, J.C., Vick, N.A., Schulman, S. and Fernandez, C. (1973) Plasmocid Encephalopathy in the Rhesus Monkey: A Study of Selective Vulnerability. Journal of Neuropathology \& Experimental Neurology, 32, 446-457. http://dx.doi.org/10.1097/00005072-197307000-00009

[56] Tateishi, J., Kuroda, S., Saito, A. and Otsuki, S. (1972) Neurotoxicity of Clioquinol in Laboratory Animals. The Lancet, 300, 1095. http://dx.doi.org/10.1016/S0140-6736(72)92392-6

[57] Tsubaki, T., Honma, Y. and Hoshi, M. (1971) Neurological Syndrome Associated with Clioquinol. The Lancet, 1, 696-697. http://dx.doi.org/10.1016/S0140-6736(71)92699-7

[58] Nevin, R.L. (2014) Idiosyncratic Quinoline Central Nervous System Toxicity: Historical Insights into the Chronic Neurological Sequelae of Mefloquine. International Journal for Parasitology: Drugs and Drug Resistance, 4, 118-125. http://dx.doi.org/10.1016/j.ijpddr.2014.03.002 
[59] Lee, C.C., Kinter, L.D. and Heiffer, M.H. (1981) Subacute Toxicity of Primaquine in Dogs, Monkeys, and Rats. Bulletin of the World Health Organisation, 59, 439-448.

[60] Brondz, I. (2013) Editorial: Analytical Methods in Quality Control of Scientific Publications Part II the Authors', Reviewers', Editors' Responsibility and the Publishers' Authority. International Journal of Analytical Mass Spectrometry and Chromatography, 1, 81-89. http://dx.doi.org/10.4236/ijamsc.2013.12010 
Scientific Research Publishing (SCIRP) is one of the largest Open Access journal publishers. It is currently publishing more than 200 open access, online, peer-reviewed journals covering a wide range of academic disciplines. SCIRP serves the worldwide academic communities and contributes to the progress and application of science with its publication.

Other selected journals from SCIRP are listed as below. Submit your manuscript to us via either submit@scirp.org or Online Submission Portal.
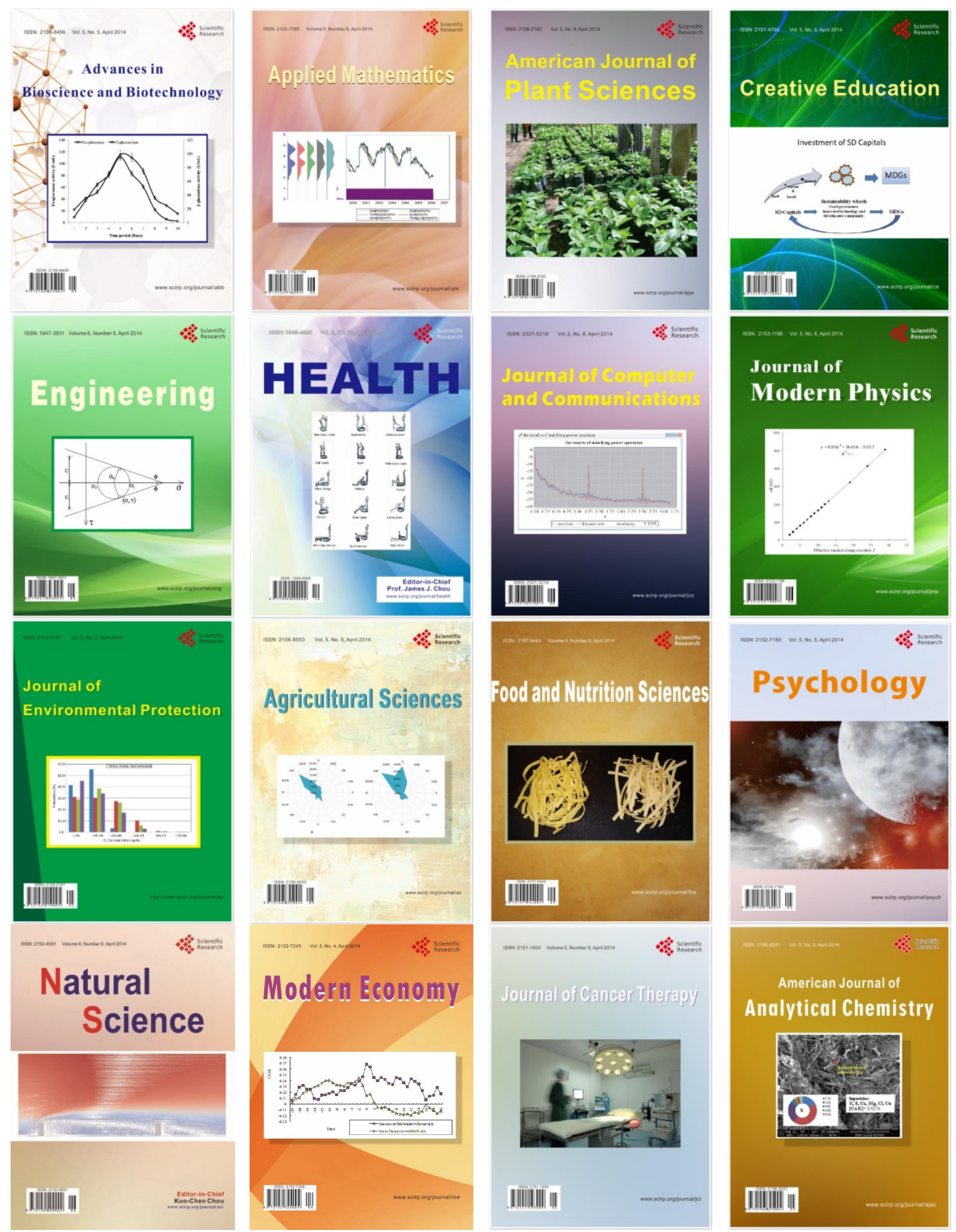